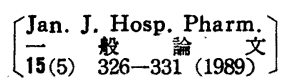

\title{
点眼㨈の投与時における用法指示の調查*1
}

\author{
中島新一郎, 河野健治, 伊藤 充, 荒井千春 \\ 山梨医科大学附属病院薬剤部*2
}

\section{The Surveillance of the Use Directions for an Eyedrop Medications by Outpatients at Yamanashi Medical College Hospital*1}

\author{
Shin'tchiro NAKAJIMA, KenJI KAWANO, Mitsuru ITO, ChIHARU ARAI \\ Hospital Pharmacy, Yamanashi Medical College*2
}

(Received April 10, 1989)

\begin{abstract}
The actual use of eyedrops was surveyed through the prescriptions for ophthalmic outpatients at Yamanashi Medical College Hospital, and the problems obtained from the results were investigated. The percentage of prescriptions which indicated the use directions for eyedrops was about 60 $\%$. $46.2 \%$ of prescriptions were under concomitant therapy which used more than two kinds of eyedrops. As the results of the compatibility tests upon mixing of eyedrops for 109 cases, the changes were observed in 29 cases. In addition, 16 samples of eyedrops were tested to determine the average drop size of each preparation. The average drop volume of different preparations varied between a minimum of $29.5 \mu \mathrm{l}$ and a maximum of $49.2 \mu \mathrm{l}$, with an average volume of $41.2 \mu 1$.
\end{abstract}

Keywords_- eyedrop medications; ophthalmic drugs; outpatients; directions for use; compatibility; drop volume

眼科領域で治療に用いられている点眼剤は多数にのぼ っており,当院眼科外来に执いても,一人の患者に数種類 の点眼剤が処方される例が多くみられる.このため, 点 眼剤の相互作用やンンュンプライアンスの問題が指摘さ れている11，さらに，点眼剤による副作用の報告もみら れ2,3)，投与時に怙ける適切な用法指示が望まれる. しか し, 点眼剤の投与時に护ける用法指示の調査に関する報 告は少ない4 6).そこで, 著者らは点眼剤の適切な服薬指 導を目的として, 処方せんの調査を行い, 得られた結果 をるとに点眼剤の配合变化試験および一滴の容量につい て検討したので報告する。

*1 日本薬学会第 108 年会（広島, 1988年 4 月）で報 告.

*2 山梨県中巨摩郡玉䄼町下河東1110;1110, Shimogato, Tamahocho, Nakakoma-gun, Yamanashi, 409-38 Japan

\section{方法}

\section{1. 処方せんの网查}

調查対象; 当院眼科外来処方せん, 調查期間; 昭和62 年 6 月 1 日 7 月 31 日, 調査内容; 点眼剤の併用之用法 指示の記載.

\section{2. 配合变化侙牌}

前述の調查の結果, 同一の眼に点眼される可能性のあ る点眼剤について検討した. 試験方法は, 溶液のものは そのまま, 用時溶解のものは添付溶解液で溶かし, 試験 管に容量比 $1 ： 1$ の割合で混合し試料とした.

実験は配合直後, 3 時間後, 6 時間後, 24 時間後の外 観変化を肉眼で観察し, $\mathrm{pH}$ はM-8 型 $\mathrm{pH}$ メーター（堀場 製作所) で, 浸透圧は漫透圧計 F-2,000 (皮点降下法, レーベリング社）を用いて経時的な变化を湘定した。 なお，保存条件は将来配合郕を院内製郕として調製する 場合も考虑して室温と冷所に保存し, また遮光の注意が 
記載されている点眼肪についてはアルミホイルで遮光し て㬰験を行った。

\section{3. 点眼郩の一流の客量}

処方せん調查の結果, 使用頻度の高い点眼剤16品目を 選び, 室温で $5 \mathrm{ml}$ のメスフラスュにできるだけゆっく りと滴下し, 正確に $5 \mathrm{ml}$ に達するまでの滴数を求め, 一滴の容量を算出した.

\section{結果と帣案}

\section{1. 処方せんの的查}

表 1 に眼科外来処方せんの調査結果を示した. 今回調 查した処方せんの枚数は, 2,164 枚であり, このらち点 眼剤の件数は全処方件数 4,155 件中 3,134 件 (75.4\%) であった.

\section{表1. 処方せんの調查}

調查期間： 62 年 6 月 1 日 7 月 31 日

\begin{tabular}{c|c|c|c|c|c}
\hline \hline $\begin{array}{l}\text { 処方せん } \\
\text { 数 }\end{array}$ 処方件数 & 内 服 & 点 眼 & 眼軟市 & 他の外用 \\
\hline \multirow{2}{*}{2164 枚 } & \multirow{2}{*}{4155 件 } & 866 & 3134 & 136 & 19 \\
\cline { 3 - 6 } & & $20.8 \%$ & $75.4 \%$ & $3.3 \%$ & $0.5 \%$ \\
\hline
\end{tabular}

次に, 点眼剤の用法指示の調查結果を表 2 , 表 3 亿示 した. 表 2 は点眼する眼の指示の有無を示したすのであ ク，1,761 件 (56.2\%) に指示が認められた. また, 表 3 は1 日の点眼回数の指示の有無を示したものであり, 1,970 件 (62.9\%) に指示が認められた. しかし, 両者 とすそれぞれ $48.3 \%, 37.1 \%$ に指示がなく, 患者の正確 な投与を考えると, 処方せんの書き方も含め検討が必要
表 2. 点眼する眼の指示

\begin{tabular}{|c|c|c|c|c|}
\hline 点樶件数 & 指示（每） & 指示（有） & & \\
\hline \multirow{2}{*}{3,134 件 } & 1,373 & 1,761 & & \\
\hline & $43.8 \%$ & $56.2 \%$ & & \\
\hline & & 西眼 & 左樶 & 右四 \\
\hline & & 784 & 504 & 473 \\
\hline & & $44.5 \%$ & $28.6 \%$ & $26.9 \%$ \\
\hline
\end{tabular}

と考えられる.なお。, 三川らは同様の調査の結果, 点 眼回数の指示のないものが全体の約 $44 \%$ を占めたと報告 している.

今回の調查結果は $37.1 \%$ \%゙あり,それよりは少ない結 果となった.ささに，1 日の点眼回数については 5 回, 4 回が多く, 10 回以上の指示も $27 \%$ あると報告してい る ${ }^{6)}$. 著者らの調査からは表 3 に示すように 1 日 3 回の 点眼回数が最も多く (全体の $34.6 \%$ ), 5 回以上は6.3\% とまれであった。

表 4 Kは同一の眼に併用の指示があった件数とその内 分けを示した. 表に示すように併用処方は 885 件 (46.2 \%)であった. このらち 2 種類のみの併用処方は 610 件 あり,これは 109 例の組み合わせからなっていた。 また，

表3. 1 日の点眼回数の指示

\begin{tabular}{|c|c|c|c|c|c|c|}
\hline 点樶件数 & 指示（無） & 提示（有） & & & & \\
\hline \multirow{2}{*}{3,134} & 1,164 & 1,970 & & & & \\
\hline & $37.1 \%$ & $62.9 \%$ & & & & \\
\hline 1 回 & 2 回 & 2～3回 & 3 回 & 3 4 回 & 4 回 & 5 回 $\uparrow$ \\
\hline 79 & 408 & 7 & 682 & 12 & 657 & 125 \\
\hline 1. $0 \%$ & $20.7 \%$ & $0.4 \%$ & $34.6 \%$ & $0.6 \%$ & $33.4 \%$ & 6. $3 \%$ \\
\hline
\end{tabular}


表 4. 同一の眼に点眼された併用件数

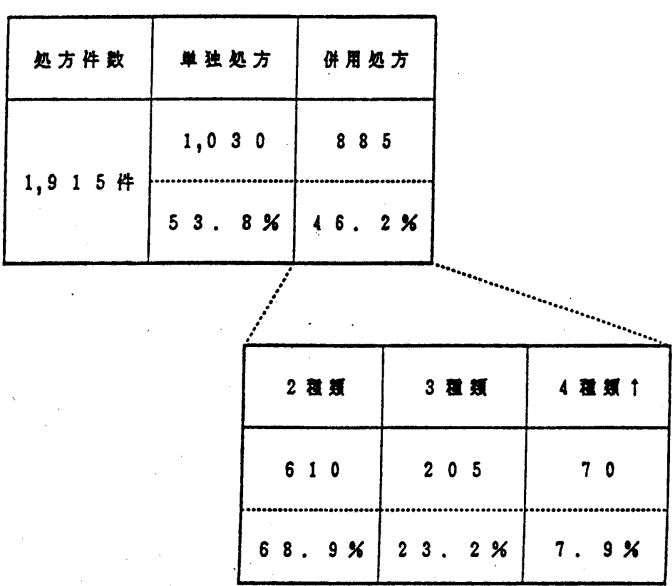

表 5. 配合変化㑢䤅結果

( 2 種類のみ)

\begin{tabular}{|c|c|c|c|}
\hline 件用甜 & 保存 & 㚆化（㷂） & 变化（市） \\
\hline \multirow{2}{*}{109 代 } & 空 & $80(73.4 \%)$ & $29(26.4 \%)$ \\
\hline & 所 & $83(76.1 \%)$ & $26(23.9 \%)$ \\
\hline
\end{tabular}

\begin{tabular}{|c|c|c|c|}
\hline 保右 & 外㬉 & P $\mathrm{H}$ & 腹运正 \\
\hline 室潍 & $27(93.1 \%)$ & $7(24.1 \%)$ & $4(13.8 \%)$ \\
\hline 所 & $25(96.2 \%)$ & $3(11.5 \%)$ & 0 \\
\hline
\end{tabular}

表 6. 配 合 変 化 試 験 結 果

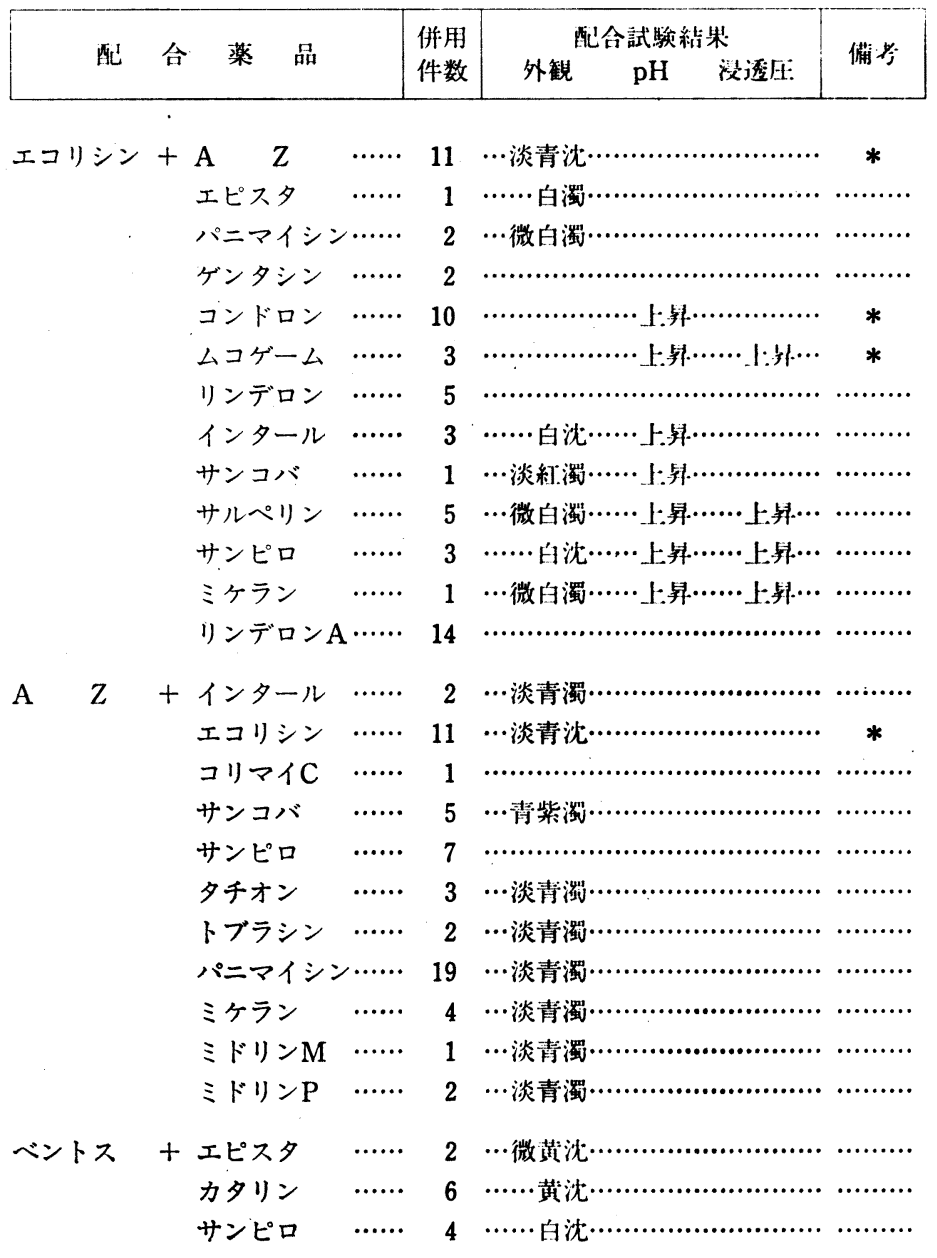

（：篹験結果が他の文献報告と異なったもの） 
処方頻度の高いものはエコリシンナフルメトロン (52 件), サンピロ+ミケラン (52件), サンピロ十チモプト ール (44件), コンドロントフラビタン (35件), エコリ シン+フラビタン (20件) などであった. な拉， 1 種類 のみの処方は 1,030 件 $(53.8 \%)$ であった.

\section{2. 処方せん調查から得られた問原点}

1）配合変化試験

2 種類以上の併用処方は前述したように, 処方件数の $46.2 \%$ に認められる. 点眼剂を同時に併用した場合, 配
合変化を生じることもあり，それらを考虑して投薬窓口 での服薬指導が必要である.ここでは, 前述の 109 例の組 み合わせについて配合変化試験を行った. 測定結果を表 5 に示した。表に示すように, 室温保存では 109 例中29 例 $(26.6 \%)$ 飞変化が認められ，これは処方件数 610 件 中 116 件 (19\%) にあたる. 外観变化については，24時 間後までに色調の変化, 沈殿（結晶析出）の生じたもの

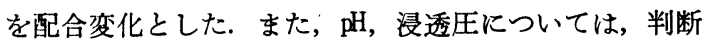
の基集がなく"

表 7. 配合変化武験結果

\begin{tabular}{|c|c|c|c|c|c|c|c|c|c|c|c|c|c|c|c|c|c|c|c|c|c|c|c|c|c|c|c|}
\hline & 1 & 2 & 3 & 4 & 5 & 6 & 7 & 8 & 9 & 10 & 11 & 12 & 13 & 14 & 15 & 16 & 17 & 18 & 19 & 20 & 21 & 22 & 23 & 24 & 25 & 26 \\
\hline & & $\begin{array}{l}\mathrm{I} \\
\mathrm{D} \\
\mathrm{U}\end{array}$ & $\begin{array}{l}3 \\
+ \\
0 \\
5 \\
v\end{array}$ & $\begin{array}{l}1 \\
\dot{y} \\
y \\
1 \\
ル\end{array}$ & $\begin{array}{l}x \\
\exists \\
y \\
\dot{y} \\
y\end{array}$ & $\begin{array}{l}A \\
Z\end{array}$ & 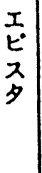 & $\begin{array}{l}\text { D } \\
\text { 多 } \\
\text { 告 }\end{array}$ & 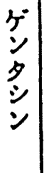 & $\begin{array}{l}z \\
y \\
z \\
1 \\
c\end{array}$ & $\begin{array}{l}コ \\
\dot{v} \\
5 \\
a \\
\nu\end{array}$ & 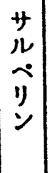 & $\begin{array}{l}\text { 晜 } \\
\text { バ }\end{array}$ & 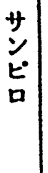 & 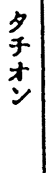 & $\begin{array}{l}f \\
z \\
z \\
1 \\
1 \\
U\end{array}$ & $\begin{array}{l}5 \\
z^{*} \\
\bar{z} \\
\vdots \\
\vdots\end{array}$ & 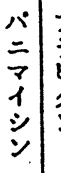 & 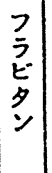 & $\begin{array}{l}J \\
u \\
x \\
r \\
a \\
\nu\end{array}$ & & $\mid \begin{array}{l}\Sigma \\
5 \\
5 \\
\vdots \\
V\end{array}$ & 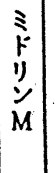 & 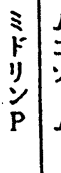 & $\begin{array}{l}\Delta \\
د \\
\forall \\
1 \\
\Delta\end{array}$ & 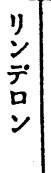 & 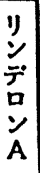 \\
\hline 1 & $I D U$ & 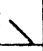 & & & & & & & & & & in & & & & & & 0 & & & & & & & & & \\
\hline 2 & アトロピン & & $\Delta$ & & & & & & & & & & & & & & & 0 & & & & & & & & $\square$ & 0 \\
\hline 3 & ヘンタール & & & $\triangle$ & Q & D & & 0 & & & Q & 페요 & 인 & & |inil & 뻬에 & & 䡩 & & 0 & 掣 & & 棒 & 菲 & 1iㅔ & & ㅁ \\
\hline 4 & エコリシン & & & 무 & 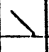 & 무 & 미 & 0 & (2) & & a & $\square$ & $\square$ & $\square$ & 㮶 & inil & 踏 & 미 & 으 & 0 & H\#! & a & 彗 & 輩 & 口 & 0 & 0 \\
\hline 5 & A 2 & & & a & D & $\Delta$ & 踣 & 0 & & Q & 0 & 典 & a & 0 & 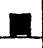 & 盅 & a) & a & Q & & 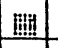 & a & a & n & 0 & & - \\
\hline 6 & エピスタ & & & & a & ini: & $>$ & 0 & & & & & & a & & 아 & & & 아 & & $\square$ & 0 & & & & & \\
\hline 7 & カタリン & & & 0 & 0 & 아 & 으 & $\triangle$ & & & 아 & & 0 & (2) & & o & 0 & 0 & 아 & & $\square$ & & & 은 & 으 & & - \\
\hline 8 & ゲンタシン & & & & 0 & & & & $>$ & & & 아 & & & & & & & & & & & & 脽 & & 이 & - \\
\hline 9 & בリマイC & & & & & (1) & & & & $\nabla$ & 0 & & 무 & & & & & & - & 0 & & ㅁ & & 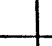 & & & Q \\
\hline 10 & コンドロン & & & 인 & a & 0 & & 0 & & 0 & 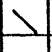 & & 우 & 0 & 은 & & 0 & 0 & 0 & 0 & & 0 & & 은 & $\square$ & 아 & - \\
\hline 11 & サルペリン & 1.1.11 & & 淎 & 무 & IIIi) & & & 아 & & - & $\Delta$ & 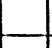 & 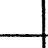 & & & e & 0 & . & & & & & 0 & & $\square$ & 监 \\
\hline 12 & サンבバ & & & 요 & ㅁ. & E & & 0 & & $\square$ & 0 & & $\Delta$ & 0 & 0 & 이 & 0 & 0 & 은 & & mat & 0 & & & 0 & & \\
\hline 13 & サンピロ & & & & a & Q & a & (2) & & & 0 & & Q & 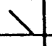 & & (2) & & & 0 & & a & Q & & & 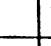 & & 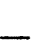 \\
\hline 14 & タチオン & & & 排 & in & a & 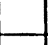 & & & & 0 & & 0 & - & 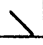 & & & & 0 & & & & & & 0 & & \\
\hline$\underline{15}$ & モモプトール & & & 渄 & 辐 & 曲 & 0 & 0 & & & 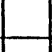 & & 0 & 0 & & $\Delta$ & & & & 0 & & & & & & 口 & \\
\hline 16 & トブラシン & & & & 뻬 & $\square$ & & 0 & & & 아 & 요 & (1) & & & & $\searrow$ & & 0 & 0 & & & & & & 으 & \\
\hline 17 & パニマイシン & 0 & 0 & 排 & a & a & & 0 & & & 이 & 아 & 0 & & & & & $>$ & o & 0 & & & & $\underline{0}$ & & 의 & 으 \\
\hline 18 & フラビタン & & & & 이 & 0 & 0 & 0 & & 0 & 0 & & 아 & 0 & 인 & & 아 & 이 & $>$ & & & & & & & & 으 \\
\hline 19 & フルメトロン & & & 아 & 0 & & & & & o & 이 & & & & & 0 & 아 & e & & 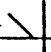 & 0 & & & Q & & & \\
\hline$\underline{20}$ & ベントス & & & 煡 & 曲 & 㤟曲 & a & E & & & & & "n: & 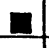 & & & & & & 0 & $\Delta$ & & & 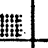 & & & . \\
\hline 21 & ミケラン & & & & a & a & 0 & & & a & 0 & & 0 & (2) & & & & & & & & $>$ & & Q & & e) & Q \\
\hline 22 & ミドリンM & & & 渄 & "⿻口卄! & $\square$ & & & & & & & & & & & & & & & & & & & & & \\
\hline$\underline{23}$ & ミドリンP & & & 渄 & (1)!il & a & & 0 & 非 & & 0 & 0 & & & & & & 아 & & 0 & 期 & 은 & - & 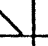 & & 0 & \\
\hline$\underline{24}$ & ムコソ゚ーム & & & 非 & a & 요 & & 0 & & & 口 & & 0 & & 0 & & & & & & & & & & & & \\
\hline$\underline{25}$ & リンデロン & & a & & 0 & & & & 일 & & 0 & a & & & & E & 0 & 은 & & & & 0 & $S$ & Q & & $>$ & - \\
\hline 26 & リンデロンA & & 0 & a & 10 & & & & & 0 & & nin| & & & & & & 0 & 0 & & & $\mathrm{O}$ & & & & & $\searrow$ \\
\hline
\end{tabular}

○ : 処方されたものて舞化の哭かった配合好

○ : 処方されたものて变化か粠かったと報告されているもの
: 処方されたものて变化を生じた双合似 Iiㅔ : 外钼变化を生じたと報告されているもの 
等を参考にし8)，ここでは経時的なpH，浸透圧の変化が 認められ，かつ24時間後の值が初期のそれと比べてそれ ぞれ 0.4，7.0 以上变化したものを配合变化とした. な お，冷所保存のすのは26例 $(23.9 \%)$ 飞变化が認められ た.

次に, 配合変化の多かったエコリシン, A Z , ベント ス $(0.5 \%)$ の試検結果を示した(表 6$)$. それぞれ，13例 中10例に，11例中 9 例に，3例中すべてに配合変化が認 められこれらの点眼郕と他郕との併用に際しては注意 が必要と考えられる.なお，(*) 印の試験結果は鈴木ら の報告1) と異なった例である．これは，著者らは経時的 な变化を測定したのに対し，配合直後のみの結果を示し たためと推定される.

表 7 には，鈴木らの報告も含め 109 例の配合変化試験 結果を示した1)。この結果から，インタール(11例)，エ コリシン (16例)，A Z (13例)，ベントス（8例）飞配 合変化が多く認められ，これらを処方する場合はとくに 往意が必要と思われる.

2）点眼戍の一滴の容量

最近になって，チモロールによる徐脈，不整脈あるい は呼吸困難等の点眼郕による副作用の報告がみられるよ らになった ${ }^{2,3)}$.これをさけるには正確な投与量の設定が 必要であり，一滴の容量を正確に知ったうえでの点眼回 数の的確な指示が望まれる，そこで，ここでは点眼㓣の 一滴の容量を求め，その結果を表 8 亿示した，表には調 查の結果使用頻度の高かった点眼用16品目の $5 \mathrm{ml}$ あた りの滴数と一滴の容量を示した. 一滴の容量の最小値, 最大値，平均値はそれぞれ $29.5 \mu \mathrm{l} ， 49.2 \mu 1 ， 41.2 \mu \mathrm{l}$ であ り点眼量に大きなひらきが認められる.

なお，通常，市販点眼肪の一滴の容量は40〜 50 $\mu 1$ また

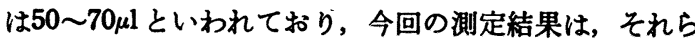
よりは少ない值となった

今回の調查結果から, 当院眼科外来の処方件数のうち 75.4\%に点眼片が処方されていることがわかった． た，点眼倣の用法指示については，点眼する眼の指示の ないものか343.8\%，1 日の点眼回数の指示のないものが $37.1 \%$ と多く，医師が直接患者に用法口授していること を考虑しても，患者の正確な投与を考えると，薬㓮師の 服薬指導のみならず処方せんの書き方も含め検討が必要 と思われる.

配合変化試験では，処方せん調査で併用が認められた 109例の組み合わせ件数中 29 例 (室温保存) 飞変化が認 められた.これは 2 種類のみの併用処方件数 610 件中116
表 8. 市眨点眼㧩の一滴の容量

\begin{tabular}{|c|c|c|c|}
\hline 品 & Lot No. & $\begin{array}{l}\text { 滴 数 } \\
(5 \mathrm{ml})\end{array}$ & 滴量 \\
\hline トブラシン & QD01 & 101.7 & 49.2 \\
\hline リンデロンA & QF01 & 102.3 & 48.9 \\
\hline ゲンタシン & 51F021 & 103.0 & 48.5 \\
\hline フラビタン & GU269 & 105.7 & 47.3 \\
\hline リンデロン & QE02 & 106.7 & 46.9 \\
\hline タチオン & EHE11 & 112.7 & 44.4 \\
\hline ミケラン (1\%) & 7B87V1 & 120.3 & 41.6 \\
\hline エピスタ & M116 & 120.7 & 41.4 \\
\hline サンコバ & SK476 & 121.3 & 41.2 \\
\hline パニマイシン & DKOS041 & 122.3 & 40.9 \\
\hline A $Z$ & G746 & 127.0 & 39.4 \\
\hline エコリシン & EC53 & 131.3 & 38.1 \\
\hline ベントス $(0.5 \%)$ & D61111 & 137.0 & 36.5 \\
\hline = $⿻ コ 一$ & E 73720 & 147.0 & 34.0 \\
\hline ミドリンP & MP306 & 157.3 & 31.8 \\
\hline $\begin{array}{r}\text { チモプートル } \\
(0.5 \%)\end{array}$ & B131K & 169.3 & 29.5 \\
\hline 平 & 均 & 124.1 & 41.2 \\
\hline
\end{tabular}

件（19\%）に処方されていた，点眼肪の併用による性状 変化は，新たな生成物を生じて有効性を減弱させるだけ でなく，有害物質の生成の可能性もあり，臨床上大きな影

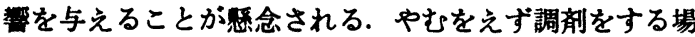
合は点眼時刻を調節するなどの服薬指導が必要と思われ

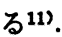

また点眼郕の一滴量では，湘定した16品目の最小値， 最大値，および平均值はそれぞれ 29.5 $\mu 1,49.2 \mu 1,41.2$ 监であり，投与量に大きなひらきが認められた．内服薬 については, 服用量が明示されているのに対し, 点眼㓮 の投与量に影篦を与える点眼回数や一滴の容量について はあまり注意が払われていないのが現状である．点眼郕 による副作用も最近報告されており，製鼡設計の段階か ら一滴の容量を十分考虑する必要があると考えられる.

\section{可用文 畨}

1）鈴木広幸, 三川武彦, 庄司羊雄, 日本病院薬郕師 会嚾誌, 22, 367-369 (1986).

2) E.M. Van Buskirk; Ophthalmology, 87, 447$450(1980)$.

3）本瀨资治，“点眼用”，南山堂，1986，pp. 329333.

4）真田幸良, 北瀑式文, 高杉益充, 福地 担, 吉本 与一, 渡边敬一, 片山孝一, 薬郕学, 40 , 別冊付 録, 47-48 (1980).

5）三川武彦，鈴木広幸，庄司羊雄，病院鿓学，13， 
321-326 (1987).

6）三川武彦，鈴木広幸，左司達雄，日本病院薬剂師 会雑芯，22，263-265 (1986).

7) 小沢知世治, 山袥子, 斉藤弥, 永田翼, 桝 㴊幸吉, 日本病院薬剂師会雑誌, 22, 1093-1095 (1986).

8) 中島新一郎, 河野健治, 伊藤宠, 荒井千春, 病
院薬学, 15, 229-234 (1989).

9) C.M. Lederer, R.E. Harold, Am. J. Ophthalmol., 101, 691-694 (1986).

10) R.H. Brown, M.L. Hotchkiss, E.B. Davis, Am. J. Ophthalmol., 99, 460-464 (1985).

11) S.S. Chrai, M.C. Makoid, S.P. Eriksen, J.R. Robinson, J. Pharm. Sci., 63, 333-338 (1974).

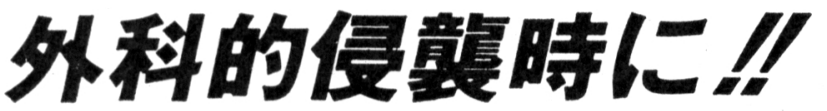

5\%ブドウ糖加アセテートリンゲル液

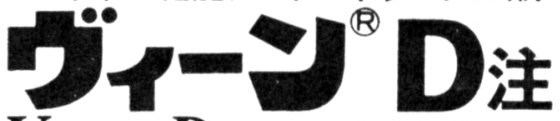
Veen-D Inj. 健保適用

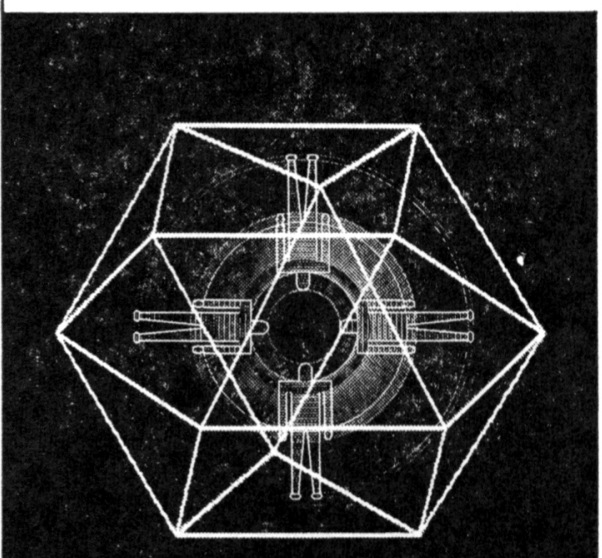

特 徵 1.アルカリ化剤としての醀酸は、全身で速やかに代謝

2エネルギー源としてのブドウ糖は、全身で速やかに 2・利用される生理的な糖質です。

〔効能・効果〕

循環血液量および組織間液の隇少時に おける細胞外液の補給・補正、代㛛性 アシドーシスの補正、エネルギーの補 給。

\section{[使用上の注意]}

(1) 次の患者には慎重に投与すること

腎疾患に基づく腎不全のある患者

の心不全のある患者

高張性脱水症の患者

閉塞性尿路疾患により原量が減少 している患者

○糖尿病の患者
(2)副作 用 大量・急速投与 脳浮腫、肺水腫、末梢の浮腫があらわ れることがある。

(3)小児への投与

小児に対する安全性は確立していない (使用経験が少ない)。

(.4) 適用上の注意

○本剤はカルシウムを含有するため、 クエン酸加血液と混合すると凝血を 起こす恐れがあるので注意すること。

リン酸イオン及び炭酸イオンと沈 殿を生じるので、リン酸又は炭酸 を含む製剤と配合しないこと。 